DOI: $10.24193 /$ tras.SI2020.4

Published First Online: 11/23/2020

\section{RESILIENCE IN TIMES OF PANDEMIC: IS THE PUBLIC PROCUREMENT LEGAL FRAMEWORK FIT FOR PURPOSE?}

\author{
Laura-Alexandra FARCA \\ Dacian C. DRAGOȘ
}

\section{Laura-Alexandra FARCA}

Attorney-at-law, PhD candidate, Faculty of Law, Babeș Bolyai University, Cluj-Napoca, Romania E-mail: laura.farca@farcalaw.ro

\section{Dacian C. DRAGOS}

Professor, Department of Public Administration and Management, Faculty of Political, Administrative and Communication Sciences,

Babeș Bolyai University, Cluj-Napoca, Romania

E-mail:dragos@fspac.ro

\footnotetext{
* Acknowledgment: This work was supported by a grant of Ministry of Research and Innovation, CNCS-UEFISCDI, project number PN-III-P4-ID-PCCF-2016-0166, within PNCDI III project ReGrowEU - Advancing ground-breaking research in regional growth and development theories, through a resilience approach: towards a convergent, balanced and sustainable European Union.
}

\section{Abstract}

This article aims to analyze whether the legislation enacted in the field of public procurement in Romania, based on the 2014 EU Directives, is effective in fostering resilience of the public institutions and indirectly of communities, and to provide a fit-for-purpose mechanism for dealing with the pandemic generated by the new type of coronavirus, Sars-CoV-2. The article discusses the necessity of new rules meant to promote swiftly purchases during the state of emergency.

Undoubtedly, the pandemic generated crisis has raised some serious challenges to which public procurement regulations is in principle properly equipped to deal with: urgent need for supplies, works and services, but also unemployment or protection of other disadvantaged categories of people. We argue that resorting to specific tools (negotiated procedures, framework-agreements, centralized procurement, sustainable and socia procurement, reserved contracts) when carrying out swift interventions generated by the pandemic would have been more suitable during this health crisis or even for preventing the effects of this pandemic. Instead, the attention of the legislator has been concentrated only on (unnecessarily) exempting the swift purchases of medical equipment from the rule of law.

Keywords: resilience, emergency state, public procurement, transparency, infringement. 


\section{Resilience of institutions in times of crisis and the role of procurement law}

In recent years, resilience has occupied a prominent place in scientific literature and more and more interdisciplinary researches investigate the implications and importance of the concept for different fields of study. Law was one of the last fields of study to embrace the resilience paradigm. However, only law in general has been the object of resilience theorizations, not specific fields of law. However, even for law, this concept is becoming more and more relevant since the number of the new enactments expressly mentioning the concept of 'resilience' is on a constant rise since 2004. On that year, the Romanian Government has enacted the Emergency Government Ordinance no. 21/2004 regarding the national system for the management of emergency situations. This enactment mentioned the concept of 'resilience' in relation with the need to ensure the resilience of the communities when the committees for siege situations decide to implement special measures to respond to different crises such as the current pandemic. The enactment skipped a definition of the notion 'resilience'. Yet, ensuring the resilience of the communities in case of a disaster should be the main aim of the Government or the local authorities. For the purpose of this paper, we will link resilience to a specific field of law, that is public procurement law.

The concept of resilience refers to the ability of a system to bounce back or return to equilibrium following disturbance (Holling, 1973). Holling named this 'engineering resilience'. Institutions are critical for resilience of communities because institutional arrangements and decision-making procedures are key to community resilience both with respect to natural disasters and endogenous social-economic developments such as economic crisis, pandemics, and technological disruptions.

The role of public procurement is usually reconsidered after major disruptions in the society and administration. The economic crisis is one example, but it is definitely even more important to consider the role of public procurement during the ongoing pandemic crisis.

The economic crisis from 2008-2009 has had a major impact on European economies. Usually, research on the impact of the economic crisis on EU policy has primarily focused on the internal market and financial market regulations, neglecting the effect on public procurement, which is surprising, as public procurement accounts for approximately $14 \%$ of the EU GDP and involves over 250,000 contracting public authorities (Pircher, 2020, p. 509). Due to its importance, procurement can be an essential tool for the EU in its efforts to take the single market out of the crisis by promoting competitiveness and growth. Procurement has been used in the aftermath of the financial crisis to foster recovery; the question remains whether the public procurement legal framework is equipped with the right mechanisms in order to weather out new crises and shocks (European Commission, 2008).

Environmental disaster and rapid climate change cautioned government bodies and environmental protection agencies, which resulted in legislations forcing busi- 
ness organizations to restrict their carbon emissions to make their supply chain a disaster resilient supply chain. For instance, the introduction of a life-cycle approach to public procurement so that carbon emissions are seen right away from the procurement of raw materials till the distribution of finished goods through logistics. Hence, there was a strong need to fix carbon emissions and to make existing supply chain an environmentally sustainable supply chain to gain environmental disaster relief. This is one the rationale behind the amendment of the public procurement Directives from 2014 (Kaur and Singh, 2019, p. 309).

In the current epidemic crisis, the response of public authorities has been construed also with the help of the rules of public procurement. The European Commission has managed to conduct the first major EU joint procurement of medical equipment (JPA) considering the large number of Member States involved. On their turn, Member States can also make use of the negotiated procedures or simplified procurement, which were designed to help also procurement in times of crisis.

Public procurement tools such as JPA or joint procurement can promote the solidarity and political will of those local and regional governments that are on the frontline, pushing more than ever to be the drivers of change, carrying out equitable service delivery, ensuring the preservation of common resources, and promoting the right of every single person to health services in the midst of this crisis. Furthermore, the role of JPA could be increased in the future to support the acquisitions of advanced health technologies to support national fragile systems with economies of scale (Mcevoy and Ferri, 2020, p. 12).

In this context, European Commission continues to see procurement as one of the most important tools for sustainability and resilience. This is pretty obvious from the fact that procurement is listed among the top drivers for resilience in the new strategic Reflection Paper 'Towards A Sustainable Europe by 2030' (European Commission, 2019).

Have these tools been used by national governments? We try to exemplify with Romania's case in order to conclude that in times of crisis the sustainability and resilience of the public systems is overlooked and other arguments are put forward, although the legal framework enables an approach that could favor resilience.

The pandemics created a state of uncertainty that supposedly required swift legal solutions in the sector of public procurement to ensure the purchase of products and the supply of services to meet the needs of the patients. We will endeavor to clarify to what extent such solutions were indeed necessary from a legal perspective or to what degree they might violate the EU law.

In this paper, we will make a brief review of the measures adopted at the EU level (section 2) followed by the analysis of the legal provisions adopted in Romania during the emergency state (section 3), and in the end will discuss pending challenges at the end of the emergency state (section 4). 


\section{The EU's response to Covid-19 crisis: from coordinating joint procurement to issuing guidelines under the EU public procurement framework}

\subsection{JPA and measures to reduce exports of medical equipment}

The unquestionable differences among Member States (MS) of the EU in terms of access to medical equipment and measures has led to the signing of the Joint Procurement Agreement to procure medical equipment at EU level ('JPA'). In practical terms, at EU level, the European Commission concluded a framework agreement on behalf of MS wishing to take part on a voluntary basis. MS, at their turn, have concluded subsequent contracts. In general, the framework agreement (OECD, 2014) is used to cut costs by purchasing large quantities (Andrecka, 2015, p. 127). Unfortunately, this could not be confirmed during the pandemic as the control of the market rested with suppliers (Trepte, 2004, p. 113). However, the bargaining power with third countries and the avoidance of competition between Member States for the (limited) suppliers show the effectiveness of this mechanism. The European Commission applied the rules of procedure included in Regulation no. 2018/1046 on financial rules, which are comparable to the ones in the 2014 Public Procurement Directives.

The award procedure used was the negotiated procedure without prior publication for extreme urgency for the purchase of personal protective equipment, which allows swift decision on award. The evaluation factors were: $50 \%$ price and $50 \%$ qualitative elements (of which the delivery period was $35 \%$ ).

Strangely, at first, no economic operator submitted its offer at the first JPA (Sanchez-Graells, 2020, p. 84) organized by the European Commission on March 12, 2020 , probably because of the lack of supplies on the market and of the short notice on the award. Subsequently, the Commission launched five calls for tenders for the supply of medical countermeasures on February 28 (gloves and coveralls), March 17 (goggles, face shields and masks, as well as ventilators), March 19 (laboratory equipment, including testing kits), and June 17 (ICU medicines) - with participation of up to 26 countries. These initiatives have proved successful.

When conducting joint procurements, the European Commission has a coordinating role, while the Member States purchase the goods. Framework contracts following the first four joint procurement procedures have been signed, and Member States could place orders.

One of the major advantages of a JPA is that it counterbalances a number of specific risks when a contracting authority from a MS directly contacts a supplier from a third country such as China (difficulty to conduct a prior assessment of suppliers, lack of transparency of some suppliers).

Other measures taken at EU level included, among others, limitation of export of medical equipment to third countries and elimination of customs duties on imports from third countries for a temporary period of 6 months. 


\subsection{Guidance on public procurement}

On April 1, 2020, the European Commission issued guidelines that clarify the flexibility offered by EU regulations in force ('Guidance'). The Guidance makes evident that an integrated, flexible, solution-oriented approach (Sanchez-Graells, 2020) is needed to combat the pandemic and that public procurement can be a factor of building resilience for the public sector.

The first recommendations regarded the approach to the market, which needed to be flexible and swift. The Commission has set up a 'clearing house for medical equipment', for a period of 6 months, that facilitates the identification of available supplies, including testing kits, and accelerates their matching with demand by the Member States. Also, based on the Guidance, contracting authorities could make use of 'active purchase' such as: contacting potential contractors in and outside the EU by phone, e-mail or in person; hiring agents that have better contacts in the markets; sending representatives directly to the countries that have the necessary stocks and can ensure immediate delivery; contacting potential suppliers to agree to an increase in production or the start or renewal of production; using innovative digital tools such as hackathons (targeted collaborations in order to identify a solution in a timely manner) or various collaboration modalities with the business environment.

As a rule, the Guidance emphasizes the use of accelerated open and restricted tender procedures, which are available in the Public Procurement Directives from 2014 and transposing national legislation. The Guidance exceptionally recommends the use of the negotiated procedure without publication for reasons of extreme urgency. Also, other available mechanisms could be available for contracting authorities: payment through an escrow account, an updated list of suppliers or even the submission of samples or photographs of the compliant product. Moreover, MS may exceptionally derogate from the grounds for mandatory exclusion of economic operators for public health.

As a rule, the use of competitive award procedures in itself presupposes that principles of equal treatment, non-discrimination, mutual recognition, proportionality and transparency are observed (Arrowsmith, 2014, p. 237). Competition could lead to a more efficient allocation of resources for social welfare (Bovis, 2015, p. 3). However, contracting authorities can use accelerated open or restricted procedure, and the proof of urgency rests with the contracting authority (Telles and Butler, 2014, p. 137). It should be noted though that urgency specific to open and restricted procedures is different from the urgency of the negotiated procedure without prior publication.

Any prior analysis will have to take into account the specific market conditions for the product concerned and the emergency conditions of the product to be purchased. In case of market failure, the contracting authorities should also adopt strategies specific to a private buyer (Sánchez-Graells, 2015, p. 62). Any asymmetry requires adaptation.

In brief, contracting authorities enjoyed a considerable leeway in the application of accelerated award procedures (Caranta, 2018, p. 396). 
As a measure of last resort, the Guidance also emphasizes that the negotiation procedure without publication as a matter of extreme urgency is an exception of the principle of transparency (Farca and Dragoş, 2018, p. 126). Precisely, because of its exceptional nature, contracting authorities should deal this with caution. The Guidance confirms that the use of negotiated procedure without prior publication can be done even 'within a few days or even hours, if necessary'.

In practice, such swift awards are infrequent, as often, even the economic operator needs a few days to prepare the tender (verification of stocks, prices, 'green lanes' border crossing, etc.). Forcing swift awards could risk that no economic operator is interested in the award as happened for the award procedure of masks launched by the Romanian Ministry of Education (Pantazi, 2020).

The phrase of the Guidance stating that: 'the procedure may constitute a de facto direct award procedure only subject to physical/technical constraints related to the actual availability and speed of delivery' is meant to emphasize the flexibility of the procedure (Hamer, p. 218) and the fact that national governments do not have to resort necessarily to direct procurement (Dragoș, 2016, p. 200).

However, the Guidance makes clear that the medical needs of hospitals could not have been foreseen before the health crisis, so the swift procedures provided by the public procurement legislation are applicable. Other consumables or products can be purchased by negotiation without publication for extreme urgency only to the extent that they are absolutely necessary to fight the current pandemic.

Thus, normally the use of the negotiated procedure without publication should be objectively justified by reference to the existing need. If the contracting authority could have applied the open or accelerated restricted award procedure, this condition may not be met on a case-by-case basis. The European Court of Justice mentioned in its previous case law that: 'Indeed, since several months have passed between the decision to replace the software and the conclusion of the contract in question, as has been pointed out in paragraphs 9 to 11 and 70 of this judgment, it is clear that it was possible, at the very least, to conduct an accelerated restricted procedure (...)'.

The case law of then CJUE needs to be looked at taking into consideration the exceptional circumstances of the pandemic, which were never tested before in regular public procurement procedures.

\section{Romania: extended use of below threshold procurement/ negotiation without prior publication for extreme urgency}

\subsection{A chronological review}

\subsubsection{The first stage of the state of emergency}

It should be noted first that the 2014 Public Procurement Directives are fully transposed in Romanian law. The national legislation provides for the same tools to award procurement contracts: open procedures, accelerated procedures, competitive negotiated procedures, negotiation without competition (in case of urgency). 
Due to the pandemic, on March 16, 2020, the Romanian President issued State Emergency Decree no. 195/2020 and declared the state of emergency for 30 days on the basis of Emergency Governmental Ordinance no. 1/1999 regarding regime of the state of siege and of emergency.

Decree no. 195/2020 has not included any express references to the relation with the current legal framework in the field of public procurement. However, pursuant to article 10 of the Decree no. 195/2020 both central authorities as well as legal entities where the state is the majority shareholder can procure by direct procurement (without a tender or award procedure following the same rules applicable to below-thresholds or sub-dimensional procurement) equipment and materials necessary in the fight against the epidemic.

Basically, the intention was to offer the contracting authorities a wide margin of discretion to fight against the epidemic. Nonetheless, in public procurement such discretion is limited by the proportionality principle (Bovis, 2019, p. 54), a principle that contracting authorities should implement in a subtle manner due to an international context in which public health came first and market was dominated by the power of the suppliers.

Similarly, article 28 regulated the right of the local public healthcare authorities and sanitary units (e.g. hospitals, clinics) to acquire through 'direct procurement' 'materials' and 'medicines' necessary during the pandemic. This difference in wording seem to suggest that healthcare authorities could also have acquired materials and equipment needed during the pandemic and not just to fight against the pandemic. This could lead to the conclusion that it is also possible to use direct procurement to purchase any kind of medicines that were needed during the pandemic and not just to treat patients suffering from Covid-19.

However, the Decree no. 195/2020 has not included any provisions regarding the status of the public procurement contracts. As a result, the performance of public contracts remained regulated by the general framework and the Romanian Civil Code regarding force majeure, fortuitous case or hardship.

To avoid delays, article 14 expressly stated that the validity of the documents issued by the public authorities shall be prolonged should the expiry date occurs during the emergency state. The Decree no. 195/2020 has not included any provisions regarding the ongoing award procedures or holding the meetings of the evaluation committees remote or on-line. As a consequence, the award procedures continued and meetings could be held remotely.

The Romanian Agency for Public Procurement ('APP') has not provided any official guidance regarding the manner in which direct procurement should be carried out. As a good practice, we can mention the example of United Kingdom, who was one of the first states to issue such guidance.

Nonetheless, in the following days, APP issued a notice mentioning that the legal rules would apply according to their legal hierarchy. The contracting authorities were also to provide the APP information on award procedures carried out within 30 
working days from the end of the state of emergency. In the meantime, the Romanian Parliament has also approved the setting up of a commission to analyze all the awards of public contracts during pandemic crisis (Marinescu, 2020). In other words, these were all attempts to keep under control the award of contracts during the crisis and to make sure that any abuses of the emergency legislation are reviewed afterwards.

On the other hand, it is noteworthy to underline that Government Emergency Ordinance no. 11/2020 expressly regulated the right of National Centralized Purchasing Office to conclude framework agreements (Vornicu, 2018), using the negotiation without prior publication for extreme urgency.

\subsubsection{The second stage: Extension decree}

The Romanian President has decided to extend the emergency state from April 16 to May 16 on the basis of the Decree no. 240/2020 ('Extension Decree') due to an ascending curve of the recorded cases. Unlike the first decree, the Extension Decree mentioned in the preamble the need to adapt the public procurement framework to take account of 'price volatility' and 'export restrictions'. Paragraph 6 of the Extension Decree's Preamble also mentions specific references to products for which the purchase is urgent: '(.) protective materials and equipment, disinfectants, medicinal products, sanitary materials, medical devices or other products necessary for the management of the pandemic'.

It is noteworthy to mention that the Decree no. 240/2020 underlines the need to use the framework agreement concluded by negotiation without prior publication for extreme urgency (art. 33 of the 2014 Directive and art. 114 of the Law no. 98/2016 on public procurement) by the institutions involved in defense, public order and national security. These institutions could procure 'specific means of protection and intervention'. Still, no definition of this notion has been provided. However, a reasonable interpretation should take into account all the elements mentioned in the preamble.

The Extension Decree confirms that during the emergency state the rules of direct procurement (below 30,000 EUR) shall be applicable also for procurement above the national threshold and also for procurement above the EU thresholds. Basically, as opposed to the first Decree, the Extension Decree allows also the local contracting authorities (e.g. local council, county council) to procure using direct awards even above the national/EU thresholds with minimum transparency (only after the award a notice on the winner needs to be published). The Extension Decree allowed also the local public healthcare authorities and sanitary units to procure using direct awards, expanding also the range of products to include 'protective equipment'. Moreover, the extension decree added new entities to the exempted list (National Penitentiary Administration). In our opinion it is fairly questionable if National Penitentiary Administration needed to made usage of direct procurement in order to ensure the continuity of detainees' feeding and appropriate individual hygiene. The units subordinated to the National Administration of Penitentiaries could have directly purchased food, cleaning and individual hygiene items for persons deprived of liber- 
ty, with the prior authorization of the General Director of the National Penitentiary Administration. Moreover, it seems that these items are not necessary to fight against the pandemic, as the regime of the detainees has not changed as a result of the pandemic.

In an attempt to keep the national authorities within an accountable legal regime, the Extension Decree as approved by the Romanian Parliament expressly stated that within 60 days of the end of the emergency state, the Court of Auditors will carry out a check on the management of public resources and will submit a report to Parliament including the findings.

Overall, it seems that in Romania, national health has been considered a solid ground to derogate from the Public Procurement Directive 24/2014/EU and Law no. 98/2016. The question is: was this necessary? One could note that the other EU member states that also decided to exempt the purchases in times of pandemic from the legal rules stemming from the EU public procurement law are (OECD, 2020, p. 13): Poland, Bulgaria (Dudevska and Stoykova, 2020) and Hungary (Petranyi et al., 2020) with a caveat that Hungary has issued these derogations only for award procedures carried out outside EU. It is hard not to notice that these are the exact countries that have constant issues with the rule of law at the EU level, thus making the question more relevant.

\subsubsection{The third stage: the state of alert}

Following the state of emergency, the authorities have switched to the lighter regime, the state of alert (May 18, 2020) on the basis of the Law no. 55/2020.

The legal framework for the state of alert has touched upon public procurement procedures as well. The validity of the documents to be submitted in the relevant award procedures has been extended during the alert stage for up to 90 days from the date when alert state would have ceased (article 4 paragraph 5). The text does not state precisely to what documents it refers or when is the date such documents should have been issued. However, it might be inferred from the systematic interpretation that this refer to documents whose validity ceased during the state of emergency, replaced by the alert state.

More generally, as to the procurement award procedures to be used during the state of alert, the negotiation without prior publication notice for extreme urgency to acquire to products and services of 'immediate necessity' became the rule, instead of direct procurement. This marks a proper use of the legal framework in place (Directive 24/2014/EU and Law no. 98/2016). However, 'immediate necessity' seems to underline the restrictive manner in which it should be construed on a case-by-case analysis.

By a way of interpretation, negotiation without prior notice should not be extended to 'works', meaning procurement of infrastructure. On the contrary, the negotiation without prior publication should definitely be used strictly to contribute to raising the answer capacity to fight against the pandemic.

How long is this exemption applicable? A reasonable approach could be that the negotiation without prior publication for extreme urgency could be properly used at 
least until the WHO will officially declare that this pandemic has been eradicated and as a result the need of specific products and equipment will eventually be diluted.

\subsection{Was the derogatory regime necessary? Is it lawful? Was it effective in terms of resilience?}

In our opinion, the legal framework for public procurement in place is flexible enough to accommodate swift purchases in times of crisis. Both the EU Directives from 2014 and national laws from 2016 provide for expedite procedures and urgent procedures to be applied when there is a situation of emergency.

By enacting provisions that permitted direct procurement (which is the least documented procurement) during emergency state the Romanian state gave the impression that transparency, proportionality and accountability are forfeited during the pandemic and that 'anything goes'. Unfortunately, direct procurement or procurement below thresholds does not imply mere flexibility under the Romanian public procurement system. On the contrary, as already pointed in another article, the rules of conflict of interest under the Romanian procurement are not applicable by analogy to below threshold procurement (Farca, 2018, p. 162.). So, a procurement entity shall be bound by the rules applicable to conflict of interest regulated by the new Romanian Administrative Code which is more permissible than the Romanian procurement regulation, especially if we refer to local authorities. Instead, the recourse to negotiated procedures for extreme urgency also requires compliance with the rules of conflict of interest as regulated by the Romanian public procurement regulations.

Coupled with the notification to the European Court of Human Rights 'ECHR' that Romania has suspended from March 17 the application of the ECHR during the pandemic, this has sent a very dangerous signal. No wonder that raising awareness on abusive, unlawful and right on corrupted public spending during the pandemic has had no effect in terms of accountability for those involved.

The situation has been partially resolved during the state of alert, where the negotiation procedure was recommended instead of direct procurement, which means a return to standard procedures under the public procurement law including the rules applicable to conflict of interest.

In term of resilience, we can argue that for institutions that are competent to deal with emergency situations, the enactment of special rules during the emergency state has not helped in terms of effectiveness, as regular procedures were perfectly fit for purpose anyway. They only gave them the sense that they are 'untouchable', favoring corrupt networks that already had some grip on public institutions. The procurement of surgical masks through intermediaries at higher prices, the procurement of faulty equipment are only a few examples.

Going back to the analysis of the Romanian public procurement legal framework enacted during the pandemic, we have identified a series of risks stemming from the fact that this legislation has exempted public purchases from the rules established in the field. 
The main risk is that the legislation has been breaching the principle of priority of EU law and enables a potential risk of infringement from the European Commission.

The legal regime governing the emergency state in Romania needs to comply with all the international obligations undertaken by Romania, irrespective of such source of law (EU law, international law with specific reference to European Court of Human Rights or Agreement on Government Procurement (GPA)).

Article 36 of the Treaty on the functioning of the European Union 'TFUE' allows the member states to regulate interdictions, restrictions or equivalent measures to derogate from the free movement of the products for reasons of public health. However, in many cases public health failed at the test at Court of Justice of the European Union when assessed against the principle of proportionality (Barnard, 2019, p. 155).

It is important to stress that application of EU public procurement award procedures is deemed mandatory for EU state members. As a rule of thumb, the existence of some harmonization measures at EU level in this field does not entail to invoke public health as a derogation from article 32 of the Public Procurement Directive the use of negotiation without prior publication for extreme urgency - and to use instead direct procurement (Telles and Butler, 2014, p. 133).

The Romanian legislator has argued the need for direct procurement (below thresholds) instead of negotiation without prior notice due to urgency in order to find solutions suitable to fight against the pandemic (the volatility of the prices charged by the suppliers that eventually lead to allowing advance payments without any formal guarantee and that resorting to negotiation still requires a large amount of paperwork (Dobrotă, 2020).

Below threshold procurement (direct procurement) is less formal, and as a rule does not impose by analogy the implementation of the rules applicable to the classical award procedures (Farca and Dragoș, 2020a, p. 467). Analogy goes against of even having some national threshold and implicitly to the harmonization provided by the Public Procurement Directive on the internal market since below threshold procurement are mainly an internal issue.

Below threshold procurement are regulated in the national law by a limited number of articles, namely article 7 of the Law no. 98/2016 as well as articles 43-46 of the Government Decision no. 395/2016 (Spărios, 2020). On the other hand, if there is a certain cross-border interest, a contracting authority has the duty to comply with the principles of non-discrimination, equal treatment, transparency, proportionality as well as mutual recognition as derived from the EU liberties embedded in the TFEU.

However, coming back to the preferred solution in Romania of resorting the below threshold procedure even after the Guidance seems to go against not only to the principle of EU's law primacy but also to go against the proportionality principle (Barnard, 2019, p. 155). This is so mostly because the majority of other MSs found suitable the use of negotiation without prior publication for extreme urgency, so the current legal framework for public procurement is reasonably adapted for procurement in times of crisis. 
Remains fairly questionable the resort to direct procurement to acquire other products or equipment, except for the medical ones (Lofstedt, 2014, p. 140) or the ones used to fight against the pandemic. In these cases, such measures could be deemed as inadequate.

Bearing in mind that Guidance recommends as a last resort the negotiation procedure without prior publication for extreme urgency, we consider the Romanian legislation during the state of emergency allowing for direct procurement regardless of thresholds can be regarded as a violation of the principle of priority of EU law. In that respect, the European Commission could initiate infringement proceedings under article 258 TFEU against Romania for using direct award (below threshold procedure) even when negotiation without prior notice was feasible. However, due to political charge of such an action, due to the ongoing crisis and the recovery efforts that will ensue afterwards, it is highly unlikely it will be promoted, so Romanian authorities might get away with it.

\section{Resilience of ongoing public contracts during the pandemic. Is the legal framework flexible enough?}

An issue that has been raised during the pandemic was the faith of ongoing contracts. The Romanian public procurement law (implementing the 2014 EU Public Procurement Directives) allows for the amendment the public procurement contract without a tender subject to the following joint conditions: (i) the need for modification has been brought about by circumstances which a diligent contracting authority could not foresee; and (ii) the modification does not alter the overall nature of the contract; the increase of price is not higher than $50 \%$ of the value of the original contract.

Each modification should also be carried out, on case by case basis, starting from the need to achieve a balance between the need to comply with the general principles applicable to public procurement awards and to the need to achieve the desired outcome. Following the legal symmetry principle, the same principles should also be applicable in what concerns the amendment of the public procurement contract.

For example, it could be disproportionate and contrary to principles of transparency, proportionality, equal treatment for several economic operators to terminate the ongoing public procurement contract in order to conclude a new public procurement contract to supply mask to much higher prices. It seems that such a situation occurred in Poland and the President of the Office of Competition and Consumer Protection was informed on time and initiated proceedings on unfair conduct against these two entities (Bogdanowicz, 2020).

The Romanian legal provisions concerning public procurement do not include a special derogation concerning force majeure, although public procurement contracts feature in principle provisions regarding this occurrence. Therefore, force majeure caused by the pandemic, even if it does not operate automatically, could be invoked by any interested economic operator based on the Romanian Civil Code (Vasilescu, 
2017, p. 608) bearing in mind to balance the risk (Rațiu, 2018, p. 68) in a mutual acceptable manner (Gherghina, 2019). This is also in line with the Recital (109) from the Directive 24/2014/EU on public sector procurement:

'Contracting authorities can be faced with external circumstances that they could not foresee when they awarded the contract, in particular when the performance of the contract covers a long period. In this case, a certain degree of flexibility is needed to adapt the contract to those circumstances without a new procurement procedure. The notion of unforeseeable circumstances refers to circumstances that could not have been predicted despite reasonably diligent preparation of the initial award by the contracting authority, taking into account its available means, the nature and characteristics of the specific project, good practice in the field in question and the need to ensure an appropriate relationship between the resources spent in preparing the award and its foreseeable value. However, this cannot apply in cases where a modification results in an alteration of the nature of the overall procurement, for instance by replacing the works, supplies or services to be procured by something different or by fundamentally changing the type of procurement since, in such a situation, a hypothetical influence on the outcome may be assumed'.

As for force majeure applicable to FIDIC contracts, the International Federation of Consulting Engineers (FIDIC) issued a memorandum providing examples based on a 'win-win' approach.

The pandemic can also be construed as case of hardship, and could also entail a party to renegotiate certain delivery or execution dates. Hardship can be invoked subject to the following (Moreanu, 2018, p. 25): (i) the change of circumstances as well as their effects could not be reasonably foreseeable at the time of the conclusion of the public procurement contract, and (ii) the debtor of the said obligation (e.g. economic operator) did not assume the risk of a change in circumstances, nor could it reasonably be considered to have taken such risk.

For this reason, the waiver of right to invoke hardship included in several public procurement contracts for supply of products should be tested for 'reasonability' in what concerns the possibility to anticipate the change in circumstances.

In conclusion, there are enough legal provisions in order to ensure the adaptation, extension or even termination of public contracts during the pandemic crisis, and thus to ensure resilience of public institutions affected by the exceptional circumstances. The balancing of affected interests should be at the base of the decision to extend, modify, suspend or terminate such ongoing contracts, and this needs to be done with caution. In terms of resilience, the local economic operators can be adversely affected by termination and indirect the community can be hit as well. 


\section{Concluding remarks: resilience in times of pandemic through the lens of legislation}

In this paper we tried to analyze the derogating legislation enacted in Romania in the field of public procurement from the perspective of resilience of administrative systems: did it help the communities to be more resilient and adaptive during the crisis? Was it necessary considering the legislative framework in place already?

In our opinion, the 2014 Directives on public procurement offer enough legal mechanisms to adapt the procurement procedures to an ongoing public health crisis.

The solution adopted during the alert state - to encourage responsible use of the existing mechanism such as the negotiation without publication of a tender notice (art. 33 of the 24/2014/EU Directive and art. 114 of the Law no. 98/2016) is the correct approach. Unfortunately, during the state of emergency, the Romanian authorities have chosen to disregard entirely the EU legislation and allowed direct procurement, which is less transparent and entails less accountability (Farca and Dragoș, 2020b, p. 287).

Many features of the EU legislation were not used at all, or used in a faulty way. For instance, one of the solutions used in European Union was to aggregate demand and organize joint procurement - for instance the joint procurement of medical equipment organized by the European Commission as a response to the COVID-19 crisis.

Aggregation techniques are used to improve cost-saving and the efficiency of procurement. One aggregation technique commonly used is centralized purchasing. This involves centralized procurement bodies (CPBs) purchasing on behalf of others, collaborations between procurers, and the use of service providers/entities to manage the purchasing process. In Romania, the Centralized Procurement Agency organized a procurement of medical equipment that was deemed faulty, leading to questions of corruption and bid-rigging. It was only one procedure of this kind, and all other central and local authorities were left to deal with the purchase of medical equipment by themselves. In this context, a big contract awarded by a state company is suspected of bribery (Moskowitz, 2020).

Access of SMEs is still a problem as they tend to be involved only as subcontractors and not as main contractors. The studies available conclude that SMEs are somewhat underrepresented (PricewaterhouseCoopers, 2014, p. 39) in public procurement (at least in procedures above the EU-thresholds) compared to their overall weight in the economy. During crisis, the SMEs are one of the most hit economic operators, impacting on the overall resilience of communities. Alas, the procurement during pandemic has not considered the division into lots in order to allow SMEs to participate, but encouraged aggregated purchases from one vendor. This was in no way a help for communities where such SMEs activate, leading to loss of jobs and closure of businesses.

Sustainable (social, environmental) procurement is one of the drivers of resilience in communities. In times of crisis, swift procurement tends to overlook the fact that 
unemployment, clean technologies, promotion of SMEs, protection of disabled or otherwise disadvantaged workers are matters that are getting worse due to pandemic and need to be addressed by communities in order to foster their resilience.

However, the institutions that have the capacity to drive the change in this field are still at national level. There was no coordination from the Commission on sustainable objectives during pandemic procurement, apart from existing methodologies on how to use green procurement criteria when procuring different types of works, services and products. Consequently, the sustainable procurement is left mainly at state's discretion. For instance, in Romania there was no concern whatsoever to guide through public procurement public funding for social objectives (hiring unemployed people, awarding contracts to sheltered workshops, etc.), although it could have been easy to do.

So, in terms of using sustainable procurement to weather the crisis and help the resilience of communities, we argue that the practice of procurement during the pandemic was a missed opportunity.

Summarizing all the above, the EU and national legal framework are enablers of resilience in times of crisis. They were not ascertained well by national decision makers during the pandemic, and thus they were not used at full potential for swift purchases. Resorting to direct procurement was unnecessary and even unlawful, it encouraged thrift, opaqueness and lack of accountability.

The pandemic could have been used as an opportunity to purchase more sustainably and thus help the recovery of communities in the aftermath of the crisis, but this aspect, although permitted and encouraged even by the legislative framework, was disregarded altogether.

\section{References:}

1. Andrecka, M., 'Framework Agreements, EU Procurement Law and the Practice', 2015, Procurement Law Journal, no. 2, pp. 127-149.

2. Arrowsmith, S., The Law of Public and Utilities Procurement: Regulation in the EU and UK, London: Sweeet \& Maxweel, Thomson Reuters, 2014.

3. Barnard, C., The Substantive Law of the EU, Oxford: Oxford University Press, 2019.

4. Bogdanowicz, P., 'Analysis: 'European Union Public Procurement during the Coronavirus Outbreak', [Online] available at https://eulawlive.com/analysis-european-union-pub lic-procurement-during-the-coronavirus-outbreak-by-piotr-bogdanowicz/, accessed on August 10, 2020.

5. Bovis, C., 'The Drivers and Boundaries of Discretion in the Award of Public Contracts', in Bogojevic, S., Groussot, X. and Hettne, J., Discretion in EU Public Procurement Law, Oxford: Hart Publishing, 2019.

6. Bovis, C., The Law of EU Public Procurement Law, Oxford: Oxford University Press, $2^{\text {nd }}$ edition, 2015.

7. Caranta., R, 'Commentary to the Article 27 Open Procedure of the Directive 2014/24/EU', in Steinicke, M. and Vesterdorf, P. (eds.), EU Public Procurement Law, Brussels Commentary, Baden-Baden: Nomos, 2018. 
8. Dobrotă, E.M., 'Aplicarea negocierii fără publicare prealabilă, din motive de extremă urgență' [The Implementation of Negotiation Without Prior Publication for Extreme Urgency], May 26, 2020, [Online] available at https://www.juridice.ro/684380/aplicareanegocierii-fara-publicare-prealabila-din-motive-de-extrema-urgenta.html, accessed on August 10, 2020.

9. Dornean Păunescu, R.L., Excepția de nelegalitate [Illegality Plea], Bucharest: Universul Juridic, 2017.

10. Dragoș, D.C., 'Sub-dimensional Public Procurement in the European Union', in Bovis, C. (ed.), Research Handbook on EU Public Procurement Law, Cheltenham, UK: Edward Elgar Publishing, 2016, pp. 176-214.

11. Dudevska, D. and Stoykova, Z., 'Bulgaria: Public Procurements during the Coronavirus Crisis', April 2, 2020, [Online] available at https://www.cms-lawnow.com/ealerts/2020/04/ bulgaria-public-procurements-during-the-coronavirus-crisis?cc_lang=en, accessed on $\mathrm{Au}$ gust 11, 2020.

12. European Commission, 'Coronavirus: Commission Bid to Ensure Supply of Personal Protective Equipment for the EU Proves Successful', March 24, 2020, [Online] available at https://ec.europa.eu/commission/presscorner/detail/en/ip_20_523, accessed on August 11, 2020.

13. European Commission, 'Public Procurement: Commission Recognizes Need for Accelerated Procurement Procedure', Brussels, December 19, 2008, [Online] available at https:// ec.europa.eu/commission/presscorner/detail/en/IP_08_2040, accessed on August 9, 2020.

14. Farca, L., 'Conflict of Interests under Romanian Public Procurement Rules. Pros and Cons of the PREVENT System', in Hințea, C.M., Moldovan, B.A., Radu, B.V. and Suciu, R.M. (eds.), Proceedings of Transylvanian International Conference in Public Administration, Cluj-Napoca November 2-4, 2017, Cluj-Napoca: Accent, 2018, pp. 150-167.

15. Farca, L.A. and Dragoș, D.C., 'Achizițiile publice-viteză: un sport la care suntem campioni!' [Fast Public Procurements: A Sport in Which We Are Champions], in Dimitriu, O. (ed.), Probleme și soluții legale privind criza COVID-19 [Problems and Legal Solutions to COVID-19 Crisis], Bucharest: CH. Beck, 2020a, pp. 450-473.

16. Farca, L.A. and Dragoș, D.C., 'Les Marchés Publics en Roumanie À l'Époque du COVID-19: Entre Obscurité et Instabilité', in Pauliat, H. and Nadaud, S. (eds.), La Crise du COVID-19 Réflexions sur un Drame Sanitaire, LexisNexis, 2020b, pp. 279-291.

17. Farca, L.A. and Dragoş, D.C., 'Principiul transparenței în achizițiile publice' [Transparency Principle in Public Procurement], 2018, Dreptul, no. 9.

18. FIDIC, 'FIDIC Covid-19 Guidance Memorandum to Users of FIDIC Standard Forms of Workscontract', undated, [Online] available at https:/fidic.org/sites/default/files/ COVID\%2019\%20Guidance\%20Memorandum\%20-\%20PDF.pdf, accessed on June 6, 2020.

19. Gherghina, S., 'Despre riscuri în contractele publice cu finanţare privată' [About Risks in the Privately Financed Public Contracts], 2019, Revista Română de Drept Privat, no. 1, pp. 125-155.

20. Hamer, C.R., 'Treaty Requirements for Contracts «Outside» the Procurement Directives', in Trybus, M., Caranta, R. and Edelstam, G. (eds.), EU Public Contract Law: Public Procurement and Beyond, Bruxelles: Bruylant, 2014. 
21. Holling, C.S, 'Resilience and Stability of Ecological Systems', 1973, Annual Review of Ecology and Systematics, vol. 4, no. 1, pp. 1-23.

22. Kaur, H. and Singh, S.P., 'Sustainable Procurement and Logistics for Disaster Resilient Supply Chain’, 2019, Annals of Operations Research, vol. 283, pp. 309-354.

23. Lofstedt, R., 'The Precautionary Principle in the EU: Why a Formal Review Is Long Overdue?', 2014, Risk Management, vol. 16, no. 3, pp. 137-163.

24. Marinescu, F., 'Comisie de anchetă în parlament pentru achizițiile publice din perioada pandemiei' [Parliamentary Inquiry Commission for the Public Procurement during the Pandemic Period], June 3, 2020, [Online] available at https://www.g4media.ro/comisiede-ancheta-in-parlament-pentru-achizitiile-publice-din-perioada-pandemiei.html, accessed on June 5, 2020.

25. Mcevoy, E. and Ferri, D., 'The Role of the Joint Procurement Agreement during the COVID-19 Pandemic: Assessing Its Usefulness and Discussing Its Potential to Support a European Health Union', 2020, European fournal of Risk Regulation, pp. 1-13, forthcoming, doi:10.1017/err.2020.91.

26. Moreanu, D., 'Impreviziune. Clauze de echilibrare convențională. circumstanță imprevizibilă. creșterea salariului minim. CA București Secția a VIII-a Contencios Administrativ și Fiscal. Decizia Civilă nr. 4604/7.11.2017’ [Hardship. Clause for Conventional Balancing. Unforeseeable Circumstance. The Raise of the Minimum Wage. Bucharest Court of Appeal, Civil Decision no. 4604/7.11.2017], 2018, Curierul fudiciar, no. 1, pp. 20-26.

27. Moskowitz, E., Head of Romania's Covid Procurement Company Faces Bribery Charges', June 25, 2020, [Online] available at https://www.occrp.org/en/daily/12618-head-of-roma nia-s-covid-procurement-company-faces-bribery-charges, accessed on July 6, 2020.

28. OECD, 'Manual for Framework Agreements', 2014, [Online] available at https://www. oecd.org/gov/ethics/manual-framework-agreements.pdf, accessed on August 10, 2020.

29. OECD, Sigma, 'Application of Public Procurement Rules during the COVID-19 Crisis from the Perspective of the European Union's Procurement Directives and the Government Procurement Agreement', August 4, 2020 [Online] available at http://www.sigmaweb.org/ publications/Public-procurement-COVID-19-crisis-SIGMA-April-2020.pdf, accessed on August 11, 2020.

30. Pantazi, R. , 'Achiziția de măști pentru elevi și profesori a fost anulată de Ministerul Educației, care a lansat astăzi o nouă procedură - cu doar două săptămâni înainte de începerea școlii' [The Purchase of Masks for Pupils and Teachers Was Cancelled by the Ministry of Education, that Launched a New Procedure Today - Just One Week before the Commencement of School Courses], May 25, 2020, [Online] available at https://www.edupe du.ro/exclusiv-achizitia-de-masti-pentru-elevi-si-profesori-a-fost-anulata-de-minister ul-educatiei-care-a-lansat-astazi-o-noua-procedura-cu-doar-o-saptamana-inainte-de-in ceperea-scolii/?source=biziday, accessed on May 26, 2020.

31. Petranyi, D., Kovacs, V., Deak, P. and Szekely, K., 'Hungary Relaxes Certain Public-Procurement Rules during COVID-19 Crisis', March 23, 2020, [Online] available at https:// www.cms-lawnow.com/ealerts/2020/03/hungary-relaxes-certain-public-procureme nt-rules-during-covid-19-crisis?cc_lang=en, accessed on August 11, 2020.

32. Pircher, B., 'EU Public Procurement Policy: The Economic Crisis as Trigger for Enhanced Harmonization', 2020, Journal of European Integration, vol. 42, no. 4, pp. 509-525. 
33. PricewaterhouseCoopers, 'Price SMEs' Access to Public Procurement Markets and Aggregation of Demand in the EU', February 2014.

34. Rațiu, M.A., Dreptul achizițiilor publice. Contractul de achiziție publică. Regimul juridic aplicabil atribuirii contractului [Public Procurement Law. Public Procurement Contract. Legal Regime Applicable to the Award of Contract], $2^{\text {nd }}$ edition, Bucharest: Universul Juridic, 2018.

35. Sanchez-Graells, A., 'European Commission's Guidance on Extreme Emergency Procurement and Covid-19 - Some Thoughts and a Word on the Dyson Contract', April 1, 2020, [Online] available at https://www.howtocrackanut.com/blog/2020/4/1/european-commis sions-guidance-on-extreme-emergency-procurement-and-covid-19-some-thoughts, accessed on May 26, 2020.

36. Sanchez-Graells, A., 'Procurement in the Time of Covid-19', 2020, Northern Ireland Legal Quarterly, vol. 71, no. 1, pp. 81-87.

37. Sánchez-Graells, A., Public Procurement and the EU Competition Rules, Oxford: Hart Publishing, 2015.

38. Spărios, D.M., 'Achizițiile publice specifice stării de urgență instituite la 16 martie 2020 - scurte considerații' [Public Procurement during the Emergency State Set on March 16, 2020 - Short Observations], March 30, 2020, [Online] available at https://www.juri dice.ro/677835/achizitiile-publice-specifice-starii-de-urgenta-instituite-la-16-martie2020-scurte-consideratii.html, accessed on May 26, 2020.

39. Telles, P. and Butler, L.R.A., 'Public Procurement Award Procedures in Directive 2014/24/ EU', in Lichère, F., Caranta, R. and Treumer, S. (eds.), Modernising Public Procurement: The New Directive, Copenhagen: DJǾF Publishing, 2014, pp. 131-184.

40. Trepte, P., Regulating Procurement. Understanding the Ends and Means of Public Procurement Regulation, Oxford: Oxford University Press, 2004.

41. Vasilescu, P., Drept civil. Obligații [Civil Law. Obligations], $2^{\text {nd }}$ edition, Bucharest: Hamangiu, 2017.

42. Vornicu, R., 'Reglementarea acordului-cadru în dreptul Uniunii Europene și transpunerea prevederilor Directivei nr. 24/2014/UE în dreptul naţional' [Regulation of the Framework Agreement in European Union Law and Transposition of the Provisions of Directive no. 24/2014/EU in National Law]', 2018, Romanian Journal of European (Community) Law, vol. 4.

\section{Case law:}

43. Judgment of the Court (Eighth Chamber) of September 7, 2016, C-549/14, Finn Frogne A/S, ECLI:EU:C:2016:634.

44. Judgment of the Court (First Chamber) of November 18, 2004, Commission of the European Communities v Federal Republic of Germany, C-126/03, ECLI:EU:C:2004:728.

45. Judgment of the Court (Fourth Chamber) of October 15, 2009, Commission of the European Communities v Federal Republic of Germany, C-275/08, ECLI:EU:C:2009:632.

46. Order of the Court (Ninth Chamber) as of May 25, 2020, C-643/19, Resopre, ECLI:EU:C:2020:388. 


\section{Regulations:}

47. Decision no. 1082/2013/EU of the European Parliament and of the Council of October 22, 2013 on serious cross-border threats to health and repealing Decision no. 2119/98/CE published in the OJ L 293, November 5, 2013, pp. 1-15.

48. Decree no. $240 / 2020$ on the extension of the emergency state in Romania, published in Official Journal of Romania no. 311 from April 14, 2020.

49. Directive 2014/24/EU of European Parliament and of the Council of February 26, 2014 on public procurement and repealing Directive 2004/18/EC, published in the OJ L 94, March 28, 2014, pp. 65-242.

50. Emergency Government Ordinance no. 21/2004 regarding the national system for the management of the emergency situations, published in the Official Journal of Romania no. 361 from April 26, 2004.

51. Emergency Government Ordinance no. 61/2020 for the amendment of the Law no. 7/1996 regarding cadastral and real estate publicity, and for the amendment and supplementing the Government Emergency Ordinance no. 57/2019 regarding the Administrative Code, published in Official Journal of Romania no. 381 from May 12, 2020.

52. European Commission, 'Reflection Paper Towards a Sustainable Europe by 2030', January 30, 2019, [Online] available at https://ec.europa.eu/commission/sites/beta-political/files/ rp_sustainable_europe_30-01_en_web.pdf, accessed on August 10, 2020.

53. European Commission, Communication from the Commission Guidance from the European Commission on Using the Public Procurement Framework in the Emergency Situation related to the COVID-19 Crisis 2020/C 108 I/01, published in the OJ C 108I, April 1, 2020, pp. 1-5.

54. European Commission, Guidance from the European Commission on using the public procurement framework in the emergency situation related to the COVID-19 crisis, published in the OJ C 108I, April 1, 2020, pp. 1-5.

55. European Commission, Guidance on the Participation of Third Country Bidders and Goods in the EU Procurement Market, July 24, 2019 C (2019) 5494 final.

56. Government Decision no. 395/2016 for the approval of the secondary norms for the implementation of the provisions regarding the awarding of the public procurement contract/ framework agreement as regulated by Law no. 98/2016 regarding public procurement, published in the Official Journal of Romania no. 423 from June 6, 2016.

57. Government Emergency Ordinance no. 11/2020 on emergency medical stock, published in the Official Journal of Romania no. 102 from February 11, 2020.

58. Law no. 554/2004 on challenging administrative acts, published in the Official Journal of Romania no. 1154 from December 7, 2004.

59. Law no. 98/2016 on public procurement, published in the Official Journal of Romania no. 390 from May 23, 2016.

60. Parliament Decision no. 4/2020 for the approval of the measure adopted by the Romanian Presidency for the extension of the emergency state in Romania, published in the Official Journal of Romania no. 320 from April 16, 2020.

61. Regulation (UE, Euratom) 2018/1046 of the European Parliament and of the Council of July 18, 2018 on the Financial Rules Applicable to the General Budget of the Union, amending Regulations (EU) no. 1296/2013, (EU) no. 1301/2013, (EU) no. 1303/2013, (EU) no. 1304/2013, 
(EU) no. 1309/2013, (EU) no. 1316/2013, (EU) no. 223/2014, (EU) no. 283/2014, and Decision no. 541/2014/EU and repealing Regulation (EU, Euratom) no. 966/2012.

62. State Emergency Decree no. 195/2020, published in the Official Journal of Romania no. 212 from March 16, 2020.

63. UK Cabinet Office, 'Procurement Policy Note - Responding to COVID-19' Information Note PPN 01/20, March 2020, [Online] available at https://assets.publishing.service.gov. uk/government/uploads/system/uploads/attachment_data/file/873521/PPN_01-20_-_Re sponding_to_COVID19.v5____.pdf, accessed on May 31, 2020. 